\title{
Influence of body mass index on outcome of the mechanically ventilated patients
}

\author{
A Anzueto, ${ }^{1}$ F Frutos-Vivar, ${ }^{2}$ A Esteban, ${ }^{2} \mathrm{~N}$ Bensalami, ${ }^{1} \mathrm{D}$ Marks, ${ }^{1} \mathrm{~K}$ Raymondos, ${ }^{3}$ \\ C Apezteguía, ${ }^{4}$ Y Arabi, ${ }_{1}^{5} \mathrm{~J}$ Hurtado, ${ }^{6}$ M González, ${ }^{7}$ V Tomicic, ${ }^{8}$ F Abroug, ${ }^{9}$ \\ J Elizalde, ${ }^{10} \mathrm{~N}$ Cakar, ${ }^{11}$ P Pelosi, ${ }^{12} \mathrm{~N}$ D Ferguson, ${ }^{13}$ for the Ventila group
}

- Additional appendices are published online only. To view these files please visit the journal online (http://thorax.bmj. com)

${ }^{1}$ University of Texas Health Science Center and South Texas Veterans Health Care System, Audie L. Murphy Memorial VA Hospital, San Antonio, Texas, USA

${ }^{2}$ Hospital Universitario de Getafe \& CIBER Enfermedades Respiratorias, Madrid, Spain ${ }^{3}$ Medizinische Hochschule Hannover, Germany

${ }^{4}$ Hospital Profesor A Posadas, Buenos Aires, Argentina

${ }^{5}$ King Fahad National Guard Hospital, Riyadh, Saudi Arabia

${ }^{6}$ Hospital de Clínicas,

Montevideo, Uruguay

${ }^{7}$ Clínica Medellín y Universidad

Pontificia Bolivariana, Medellín, Colombia

${ }^{8}$ Clínica Alemana de Santiago, Santiago, Chile

${ }^{9}$ Fattouma Bourguiba, Monastir, Tunisia

${ }^{10}$ Hospital ABC, México DF, México

${ }^{11}$ Istanbul Medical Faculty, Turkey

${ }^{12}$ Department of Ambient, Health and Safety, University of Insubria, Varese, Italy

${ }^{13}$ Interdepartmental Division of Critical Care Medicine, and Department of Medicine, Division of Respirology, University Health Network and Mount Sinai Hospital, University of Toronto, Toronto, Ontario, Canada

\section{Correspondence to}

Antonio Anzueto, M.D.111E,

7400 Merton Minter Boulevard,

San Antonio, TX 78229, USA;

anzueto@uthscsa.edu

Received 17 June 2010

Accepted 30 September 2010

Published Online First

27 October 2010

\section{ABSTRACT \\ Background There are limited data on the impact of body mass index on outcomes in mechanically ventilated patients.}

Methods Secondary analysis of a cohort including 4698 patients mechanically ventilated. Patients were screened daily for management of mechanical ventilation, complications (acute respiratory distress syndrome, sepsis, ventilator associated pneumonia, barotrauma), organ failure (cardiovascular, respiratory, renal, hepatic, haematological) and mortality in the intensive care unit. To estimate the impact of body mass index on acute respiratory distress syndrome and mortality, the authors constructed models using generalised estimating equations (GEE).

Results Patients were evaluated based on their body mass index: 184 patients (3.7\%) were underweight, 1995 patients (40\%) normal weight, 1781 patients (35.8\%) overweight, 792 patients (15.9\%) obese and 216 patients $(4.3 \%)$ severely obese. Severely obese patients were more likely to receive low tidal volume based on actual body weight but high volumes based on predicted body weight. In obese patients, the authors observed a higher incidence of acute respiratory distress syndrome and acute renal failure. After adjustment, the body mass index was significantly associated with the development of acute respiratory distress syndrome: compared with normal weight; OR 1.69 (95\% Cl 1.07 to 2.69) for obese and OR 2.38 (95\% Cl 1.15 to 4.89) for severely obese. There were no differences in outcomes (duration of mechanical ventilation, length of stay and mortality in intensive care unit and hospital) based on body mass index categories.

Conclusions In this cohort, obese patients were more likely to have significant complications but there were no associations with increased mortality.

\section{INTRODUCTION}

Obesity is a global healthcare problem. ${ }^{1}$ In the United States, $35 \%$ of the adult population was recently designated as being overweight or obese. ${ }^{2}$ Although frequently analysed in the context of chronic disease, the influence of obesity on acute illness is less understood. The results of the few studies that do address this question have been pooled in three meta-analyses ${ }^{3-5}$ with differing results. Akinussi et $a l^{3}$ reported that obesity (body mass index $\geq 30 \mathrm{~kg} / \mathrm{m}^{2}$ of body surface area) was not associated with crude intensive care unit mortality in comparison with patients with a body mass index lower than $30 \mathrm{~kg} / \mathrm{m}^{2}$ of body surface area. Meanwhile, Oliveros et $a l^{4}$ found a lower mortality for obese but not for morbidly obese patients compared with those with normal weight. Lastly, Hogue et $a l^{5}$ reported that obesity is not associated with increased risk for intensive care unit mortality, but it may be associated with lower hospital mortality. Most of the studies included in these meta-analyses included general populations of patients admitted to the intensive care unit. The data related specifically to the impact of obesity on outcomes with mechanical ventilation is more limited. Bercault et al ${ }^{6}$ conducted a matched cohort study including 170 obese patients and 170 patients with a normal body mass index and found that obesity was significantly associated with intensive care unit mortality (OR 2.1; 95\% CI 1.2 to 3.6) Similarly, Frat et al ${ }^{7}$ compared 82 severely obese patients with 124 non-obese patients, and reported the only difference in morbidity of obese patients who were mechanically ventilated was an increased difficulty with tracheal intubation and a higher frequency of post-extubation stridor. Obesity was not associated either with increased intensive care unit mortality or with hospital mortality. Two studies $^{8} 9$ limited to patients with acute lung injury/acute respiratory distress syndrome showed no association between obesity and mortality, though the latter study ${ }^{9}$ showed an increase in the duration of mechanical ventilation and length of stay in obese patients. In contrast, O'Brien et al ${ }^{8}$ studied 1488 mechanically ventilated patients with acute lung injury and found that lower body mass index was associated with higher odds of death, whereas overweight and obesity were associated with lower mortality.

Given these discrepant data on outcomes of obese mechanically ventilated patients, the main objective of this study was to describe the influence of body mass index on clinical outcomes in a large heterogeneous cohort of mechanically ventilated patients.

\section{METHODS \\ Patients}

This is a secondary analysis from a prospective, multicentre, international cohort of 4968 adult patients who received mechanical ventilation for more than $12 \mathrm{~h}$ during a 1-month period beginning 1 April 2004 in 349 intensive care units (see online appendix 1 for list of centres). ${ }^{10}$ All mechanically ventilated patients admitted to the participating ICUs during the study period were consecutively enrolled. The study protocol was approved by local Institutional Review Boards of all the participating centres with a waiver for consent. 
Full details of the methodology are showed in Appendix 2, see online Briefly, the following information was collected on each enrolled patient at baseline: demographic data (gender, age, estimated weight and height at admission to the intensive care unit-we used these values to calculate the body mass index (kg/ $\mathrm{m}^{2}$ ) by dividing weight in kilogrammes by the square of the height in metres and we categorised patients, according to the National Institutes of Health (NIH) definition of obesity, as: (1) underweight: body mass index $<18.5 \mathrm{~kg} / \mathrm{m}^{2}$; (2) normal weight: body mass index $18.5-24.9 \mathrm{~kg} / \mathrm{m}^{2}$; (3) overweight: body mass index $25-29.9 \mathrm{~kg} / \mathrm{m}^{2}$; (4) obese: body mass index $30-39.9 \mathrm{~kg} / \mathrm{m}^{2}$ and (5) severely obese: body mass index $>40 \mathrm{~kg} / \mathrm{m}^{2}$-and simplified acute physiology score (SAPS II) at the time of admission to the intensive care unit); day of initiating mechanical ventilation; type of ventilation (invasive, non invasive), and primary indication for mechanical ventilation (acute on chronic pulmonary disease (chronic obstructive pulmonary disease (COPD), asthma, chronic pulmonary disease other than COPD); coma; neuromuscular disease and acute respiratory failure (acute respiratory distress syndrome (ARDS), postoperative, congestive heart failure, aspiration, community pneumonia, hospital pneumonia, sepsis, trauma, cardiac arrest, and other reason)). The following variables were collected daily until intensive care unit discharge, or to day 28, whichever occurred first: ventilator settings (tidal volume, positive end-expiratory pressure (PEEP), peak pressure, plateau pressure); use of sedatives; use of neuromuscular blockers; and complications arising (acute respiratory distress syndrome, barotrauma, ventilator associated pneumonia, sepsis, organ failure (cardiovascular failure, respiratory failure, renal failure, hepatic failure, haematological failure)). Organ failure was defined as a sequential organ failure assessment (SOFA) score higher than 2 points on at least two consecutive days. Weaning refers to the discontinuation of mechanical ventilation; the onset of weaning was defined at the time the patient had a change in ventilator mode that was consistent with weaning modality and likely to be able to resume spontaneous breathing. Patients were classified according to the weaning process into three groups as follows: simple weaning group-including patients who successfully passed the first spontaneous breathing trial and were extubated on the first attempt; difficult weaning group-including patients who required up to 7 days from the first spontaneous breathing trial to achieve successful weaning; and prolonged weaning group-including patients who required more than 7 days of weaning after the first spontaneous breathing trial. The patients were prospectively followed for outcomes until hospital discharge.

\section{Statistical analysis}

Data are expressed as mean (SD), median (IOR) and proportions as appropriate. ANOVA with Student-Newman-Keuls posthoc comparison was used to compare continuous variables with normal distribution and Kruskal-Wallis test was used to compare continuous variables with non-normal distribution. $\chi^{2}$ test was used to compare proportions. These analyses were performed with SPSS (version 17.0) statistical software.

To estimate the impact of body mass index on mortality in the intensive care unit, we used generalised estimating equations (GEE) to deal with the possibility of clustering by centre. We entered the following variables into the model: age, gender, SAPS II, body mass index category as a dummy variable taking

Table 1 Demographic characteristics of study patients

\begin{tabular}{|c|c|c|c|c|c|c|}
\hline & $\begin{array}{l}\text { Underweight } \\
\left(\mathrm{BMI}<18.5 \mathrm{~kg} / \mathrm{m}^{2}\right)\end{array}$ & $\begin{array}{l}\text { Normal } \\
\left(B M I 18.5-24.9 \mathrm{~kg} / \mathrm{m}^{2}\right)\end{array}$ & $\begin{array}{l}\text { Overweight } \\
(B M I) 25-29.9 \mathrm{~kg} / \mathrm{m}^{2} \text { ) }\end{array}$ & $\begin{array}{l}\text { Obese } \\
\text { (BMI } 30-39.9 \text { kg/m²) }\end{array}$ & $\begin{array}{l}\text { Severely obese } \\
\left(\mathrm{BMI}>40 \mathrm{~kg} / \mathrm{m}^{2}\right)\end{array}$ & p-Value \\
\hline N (\% (95\% Cl)) & $184(3.7 \%(3.2$ to 4.3$))$ & $1995(40.1 \%(38.8$ to 41.5$))$ & $1781(35.8 \%(34.5$ to 37.2$))$ & 792 (15.9\%; (14.9 to 16.9$))$ & 216 (4.3\%; (3.8 to 4.9$))$ & \\
\hline Age, years, mean (SD) & $55(19)$ & $57(19)$ & $61(17)$ & $61(14)$ & $55(14)$ & $<0.001$ \\
\hline $\begin{array}{l}\text { Body mass index, } \\
\mathrm{kg} / \mathrm{m}^{2} \text {, mean (SD) }\end{array}$ & $17(1)$ & $23(2)$ & $27(1)$ & $33(3)$ & $50(11)$ & $<0.001$ \\
\hline Female, N (\% (95\% CI)) & $84(45.6 \%(38.3$ to 51.3$))$ & $823(41.2 \%(39.0$ to 43.4$))$ & $586(32.9 \%(30.7$ to 35.1$))$ & $357(45.0 \%(41.6$ to 48.6$))$ & $117(54.1 \%(47.2$ to 60.9$))$ & $<0.001$ \\
\hline $\begin{array}{l}\text { SAPS II, points, } \\
\text { mean (SD) }\end{array}$ & $43(19)$ & $43(18)$ & $43(17)$ & $44(17)$ & $42(17)$ & 0.587 \\
\hline \multicolumn{7}{|c|}{ Reason for mechanical ventilation, N (\% (95\% Cl)) } \\
\hline $\begin{array}{l}\text { Chronic obstructive } \\
\text { pulmonary disease }\end{array}$ & $14(7.6 \%(4.2$ to 12.4$))$ & $101(5.1 \%(4.1$ to 6.1$))$ & $80(4.5 \%(3.6$ to 5.5$))$ & $56(7.0 \%(5.4$ to 9.1$))$ & $16(7.4 \%(4.3$ to 11.7$))$ & 0.025 \\
\hline Asthma & $2(1.0 \%(0.1$ to 3.8$))$ & $23(1.1 \%(0.7$ to 1.7$))$ & $20(1.1 \%(0.7$ to 1.7$))$ & $13(1.6 \%(0.9$ to 2.8$))$ & $5(2.3 \%(0.7$ to 5.3$))$ & 0.504 \\
\hline $\begin{array}{l}\text { Chronic pulmonary } \\
\text { disease }\end{array}$ & $8(4.3 \%(1.9$ to 8.4$))$ & $26(1.3 \%(0.8$ to 1.9$))$ & $20(1.1 \%(0.7$ to 1.7$))$ & $13(1.6 \%(0.9$ to 2.8$))$ & $18(8.3 \%(5.0$ to 12.8$))$ & $<0.001$ \\
\hline \multicolumn{7}{|l|}{ Acute respiratory failure } \\
\hline $\begin{array}{l}\text { Acute respiratory } \\
\text { distress syndrome }\end{array}$ & $12(6.5 \%(3.4$ to 11.1$))$ & $63(3.1 \%(2.4$ to 4.0$))$ & $44(2.5 \%(1.8$ to 3.3$))$ & $28(3.5 \%(2.4$ to 5.1$))$ & $1(0.5 \%(0$ to 2.5$))$ & 0.004 \\
\hline Postoperative & $31(16.8 \%(11.7$ to 23.0$))$ & $408(20.4 \%(18.7$ to 22.3$))$ & $384(21.6 \%(19.7$ to 23.5$))$ & $183(23.1 \%(20.2$ to 26.2$))$ & $47(21.7 \%(16.4$ to 27.8$))$ & 0.324 \\
\hline $\begin{array}{l}\text { Congestive heart } \\
\text { failure }\end{array}$ & $5(2.7 \%(0.9$ to 6.2$))$ & $112(5.6 \%$ (4.6 to 6.7$)$ & $95(5.3 \%(4.4$ to 6.5$))$ & $59(7.4 \%(5.7$ to 9.5$))$ & $14(6.5 \%(3.6$ to 10.6$))$ & 0.084 \\
\hline Aspiration & $9(4.9 \%(2.3$ to 9.1$))$ & $64(3.2 \%(2.5$ to 4.1$))$ & $47(2.6 \%(1.9$ to 3.5$))$ & $17(2.1 \%(1.2$ to 3.4$))$ & $2(0.9 \%(0.1$ to 3.3$))$ & 0.079 \\
\hline $\begin{array}{l}\text { Community } \\
\text { Pneumonia }\end{array}$ & $23(12.5 \%(8.1$ to 18.2$))$ & $168(8.4 \%(7.2$ to 9.7$))$ & $125(7.0 \%(5.9$ to 8.3$))$ & $47(5.9 \%(4.4$ to 7.8$))$ & $13(6.0 \%(3.2$ to 10.0$))$ & 0.011 \\
\hline Hospital Pneumonia & $14(7.6 \%(4.2$ to 12.4$))$ & $63(3.1 \%(2.4$ to 4.0$))$ & $56(3.1 \%(2.4$ to 4.1$))$ & $16(2.0 \%(1.1$ to 3.3$))$ & $3(1.4 \%(0.3$ to 4.0$))$ & 0.001 \\
\hline Sepsis & $11(5.9 \%(3.0$ to 10.4$))$ & $177(8.8 \%(7.7$ to 10.2$))$ & $161(9.0(7.7$ to 10.5$))$ & $70(8.8 \%(6.9$ to 11.3$))$ & $30(13.9 \%(9.6$ to 19.2$))$ & 0.079 \\
\hline Trauma & $9(4.9 \%(2.3$ to 9.1$))$ & $111(5.5 \%(4.6$ to 6.7$))$ & $103(5.8 \%(4.7$ to 6.9$))$ & $47(5.9 \%(4.4$ to 7.8$))$ & $14(6.5 \%(3.6$ to 10.6$))$ & 0.959 \\
\hline Cardiac arrest & $11(5.9 \%(3.0$ to 10.4$))$ & $91(4.6 \%(3.7$ to 5.8$))$ & $89(4.9 \%(4.0$ to 6.1$))$ & $39(4.9 \%(3.5$ to 6.7$))$ & $9(4.2 \%(1.9$ to 7.8$))$ & 0.883 \\
\hline Other & $17(9.2 \%(5.5$ to 14.4$))$ & $173(8.7 \%(7.5$ to 9.9$))$ & $152(8.5 \%(7.3$ to 9.9$))$ & $73(9.2 \%(7.3$ to 11.4$))$ & $17(7.8 \%(4.6$ to 12.3$))$ & 0.965 \\
\hline Coma & $14(7.6 \%(4.2$ to 12.4$))$ & $386(19.3 \%(17.6$ to 21.1$))$ & $389(21.8 \%(19.9$ to 23.8$))$ & $126(15.9 \%(13.4$ to 18.6$))$ & $23(10.6 \%(6.9$ to 15.5$))$ & $<0.001$ \\
\hline Neuromuscular disease & $4(2.2 \%(0.6$ to 5.5$))$ & $29(1.4 \%(0.9$ to 2.1$))$ & $16(0.9 \%(0.5$ to 1.4$))$ & $5(0.6 \%(0.2$ to 1.5$))$ & $4(1.8 \%(0.5$ to 4.7$))$ & 0.136 \\
\hline
\end{tabular}




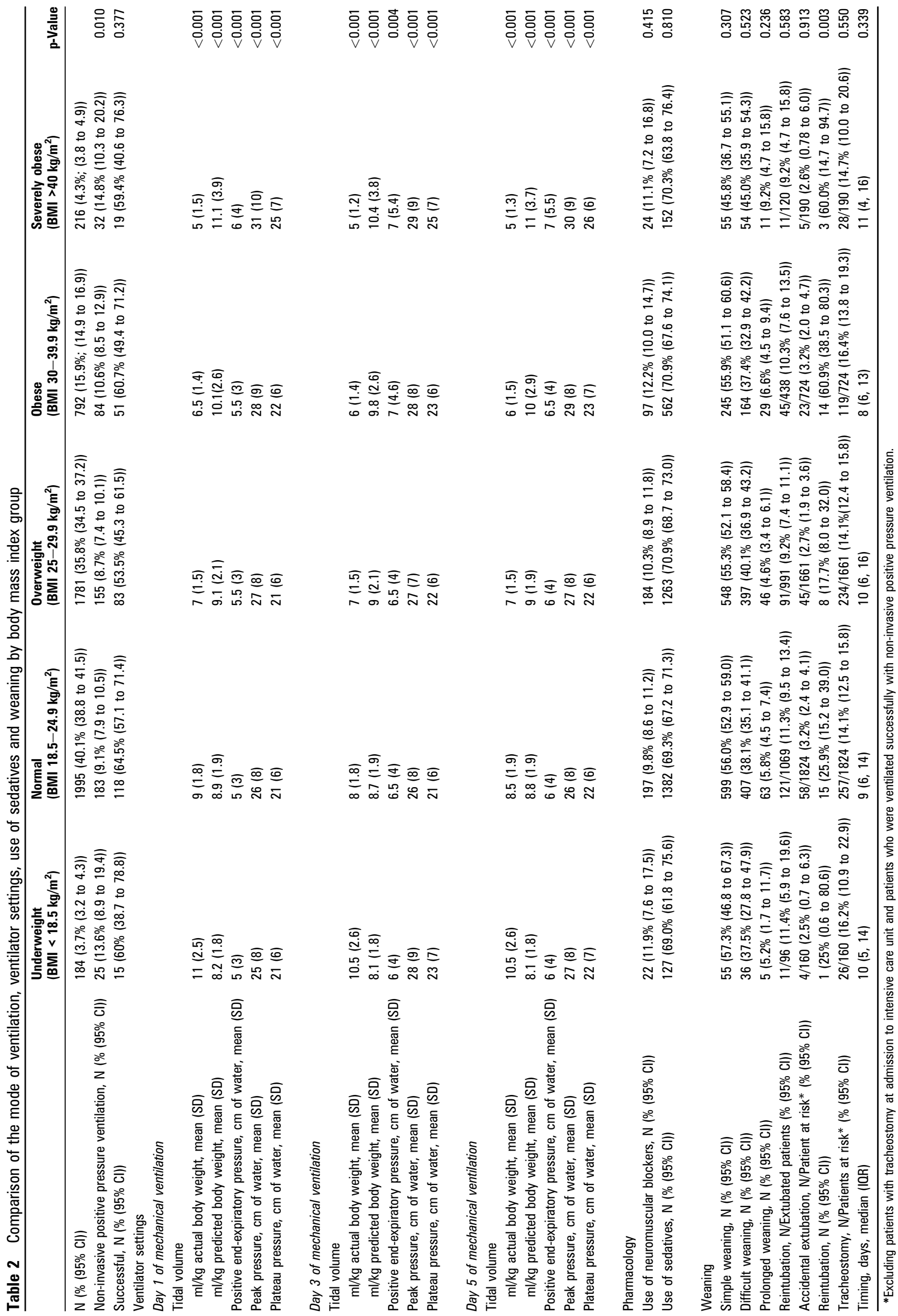


as reference 'underweight' category, type of ventilation (invasive ventilation vs. failed non-invasive ventilation vs successful non-invasive ventilation) and reason for initiating mechanical ventilation. We considered a significant $p$-value $<0.05$. This analysis was performed with Stata (version 10.0) statistical software.

After exploring the data, we observed a significant trend towards a higher incidence of ARDS, developing over the course of mechanical ventilation in obese patients. To estimate if there was an independent association between body mass index and development of ARDS, we performed a second GEE analysis. In this model, we considered the following variables: age, gender, SAPS II, body mass index category as a dummy variable taking as reference 'underweight' category (for the purpose if this analysis we categorised the body mass index into four categories: underweight, normal, overweight and obese/severely obese), reason for initiation of mechanical ventilation categorised as a dummy variable (chronic pulmonary disease, neurologic disease, acute respiratory failure causes associated with ARDS (aspiration, trauma sepsis, pneumonia), and acute respiratory failure not associated with ARDS (postoperative, congestive heart failure, cardiac arrest), risk factors for acute respiratory distress syndrome developed over the duration of mechanical ventilation (shock, sepsis, ventilator associated pneumonia) and ventilator settings (tidal volume in $\mathrm{ml} / \mathrm{kg}$ of predicted body weight and positive end-expiratory pressure). The ventilator settings entered in the analysis were values accrued until the day of ARDS diagnosis in patients who met criteria for ARDS, or the values until the start of weaning for those who did not meet ARDS criteria. This analysis was performed with Stata (version 10.0) statistical software.

\section{RESULTS}

\section{Patients' baseline characteristics}

A total of 792 patients were obese (15.9\%; 95\% CI 14.9 to 16.9 ) and 216 patients severely obese $(4.3 \%$; $95 \%$ CI 3.8 to 4.9$)$. Table 1 summarises the baseline demographic characteristics of the whole cohort.

There were significant differences in age and gender among body mass index groups. Very obese patients were more likely to be younger women as compared with other weight groups.
Obese and severely obese patients were less likely to receive mechanical ventilation due to community-acquired pneumonia or a neurological event as compared with normal weight patients.

\section{Implementation of mechanical ventilation}

Modes of ventilation, ventilator parameters, use of sedatives and weaning are summarised in table 2 .

Non-invasive ventilation was used more frequent in patients who were underweight or severely obese as compared with the other groups. Severely obese patients were more likely to receive low tidal volume based on actual body weight but high volumes based on predicted body weight. These patients were also ventilated with slightly higher levels of PEEP. There were not significant differences in the proportion of patient who reached weaning. Both obese and severely obese patients had a higher percentage of reintubation following accidental extubations compared with the other groups.

\section{Outcomes}

In obese patients, we observed a higher incidence of acute respiratory distress syndrome and acute renal failure (table 3 ).

Table 4 shows the univariable and multivariable analysis of variables related to the development of acute respiratory distress syndrome over the course of mechanical ventilation.

After adjustment, body mass index remained significantly associated with the development of acute respiratory distress syndrome (figure 1).

There were no differences in the patients' outcomes (duration of mechanical ventilation, duration of weaning, length of stay in the intensive care unit, length of stay in the hospital and mortality in the intensive care unit and in the hospital) based on body mass index categories (table 5 ).

Table 6 shows the univariable and multivariable analysis for mortality.

There was a non-significant trend towards a lower mortality with increase of body mass index (figure 2).

\section{DISCUSSION}

The main findings of this study are: increased body weight and obesity were more common in this cohort of mechanically ventilated patients than previously reported in populations of

Table 3 Comparison of complications over the course of mechanical ventilation in each body mass index groups

\begin{tabular}{|c|c|c|c|c|c|c|}
\hline & $\begin{array}{l}\text { Underweight } \\
\left(\mathrm{BMI}<18.5 \mathrm{~kg} / \mathrm{m}^{2}\right)\end{array}$ & $\begin{array}{l}\text { Normal } \\
\left(B M I 18.5-24.9 \mathrm{~kg} / \mathrm{m}^{2}\right)\end{array}$ & $\begin{array}{l}\text { Overweight } \\
\text { (BMI } 25-29.9 \mathrm{~kg} / \mathrm{m}^{2} \text { ) }\end{array}$ & $\begin{array}{l}\text { Obese } \\
\text { (BMI } 30-39.9 \mathrm{~kg} / \mathrm{m}^{2} \text { ) }\end{array}$ & $\begin{array}{l}\text { Severely obese } \\
\left(B M I>40 \mathrm{~kg} / \mathrm{m}^{2}\right)\end{array}$ & p-Value \\
\hline$N(\%(95 \% \mathrm{CI}))$ & $184(3.7 \%(3.2$ to 4.3$))$ & $1995(40.1 \%(38.8$ to 41.5$))$ & $1781(35.8 \%$ (34.5 to 37.2$))$ & $792(15.9 \%$; (14.9 to 16.9$))$ & $216(4.3 \% ;(3.8$ to 4.9$))$ & \\
\hline Barotrauma, N (\% (95\% CI)) & $8(4.3 \%(1.9$ to 8.4$))$ & $63(3.1 \%(2.4$ to 4.0$))$ & $54(3.0 \%(2.3$ to 3.9$))$ & $27(3.4 \%(2.2$ to 4.9$))$ & $5(2.3 \%(0.7$ to 5.3$))$ & 0.807 \\
\hline Sepsis, N (\% (95\% Cl)) & $22(11.9 \%$ (7.6 to 19.5$))$ & $158(7.9 \%$ (6.7 to 9.2$))$ & $155(8.7 \%(7.4$ to 10.1$))$ & $50(6.3 \%$ (4.7 to 8.2$))$ & $15(6.9 \%$ (3.9 to 11.1$))$ & 0.076 \\
\hline $\begin{array}{l}\text { Cardiovascular failure, } \\
\text { N (\% (95\% Cl)) }\end{array}$ & $60(32.6 \%(25.9$ to 39.9$))$ & $620(31.1 \%(29.0$ to 33.1$))$ & $587(32.9 \%$ (30.8 to 35.2$))$ & $224(28.3 \%(25.1$ to 31.5$))$ & $63(29.2 \%(23.2$ to 35.7$))$ & 0.179 \\
\hline \multicolumn{7}{|l|}{$\begin{array}{l}\text { Respiratory failure, } \\
\text { N (\% (95\% Cl)) }\end{array}$} \\
\hline $\begin{array}{l}\text { With criteria of acute } \\
\text { respiratory distress syndrome }\end{array}$ & $11(5.9 \%$ (3.0 to 10.4$))$ & $89(4.5 \%$ (3.6 to 5.5$))$ & $102(5.7 \%(4.7$ to 6.9$))$ & $55(6.9 \%(5.3$ to 8.9$))$ & $19(8.8 \%$ (5.4 to 13.4$))$ & 0.021 \\
\hline $\begin{array}{l}\text { Without criteria of acute } \\
\text { respiratory distress syndrome }\end{array}$ & $42(22.8 \%$ (16.9 to 29.6$))$ & $556(27.9 \%(25.9$ to 29.9$))$ & $557(31.3 \%(29.1$ to 33.5$))$ & $256(32.3 \%(29.1$ to 35.7$))$ & $81(37.5 \%$ (31.0 to 44.3$))$ & 0.002 \\
\hline $\begin{array}{l}\text { Acute renal failure, } \\
\mathrm{N}(\%(95 \% \mathrm{CI}))\end{array}$ & $12(6.5 \%(3.4$ to 11.1$))$ & $123(6.2 \%(5.1$ to 7.3$))$ & $150(8.4 \%(7.2$ to 9.8$))$ & $71(8.9 \%(7.1$ to 11.2$))$ & $26(12.0 \%$ (8.0 to 17.1$))$ & 0.003 \\
\hline
\end{tabular}


Table 4 Univariable and multivariable analysis, by generalised estimating equation models, for development of acute respiratory distress syndrome over the course of mechanical ventilation

\begin{tabular}{|c|c|c|c|c|c|c|}
\hline & Univariable & & & Multivariable & & \\
\hline & $\overline{\mathbf{O R}}$ & $95 \% \mathrm{Cl}$ & $\overline{p-V a l u e}$ & $\overline{\mathbf{O R}}$ & $95 \% \mathrm{Cl}$ & p-Value \\
\hline Age, per year & 0.99 & 0.98 to 1.00 & 0.861 & & & \\
\hline \multicolumn{7}{|l|}{ Gender } \\
\hline Male & 1 (reference) & & & & & \\
\hline Female & 0.90 & 0.65 to 1.26 & 0.550 & & & \\
\hline \multicolumn{7}{|l|}{ Body mass index by category } \\
\hline Underweight & 1 (reference) & & & 1 (reference) & & \\
\hline Normal & 1.33 & 0.57 to 3.10 & 0.507 & 1.62 & 0.58 to 4.50 & 0.352 \\
\hline Overweight & 2.04 & 0.86 to 4.84 & 0.106 & 2.23 & 0.80 to 6.22 & 0.126 \\
\hline Obese/severely obese & 2.59 & 1.11 to 6.06 & 0.028 & 3.07 & 1.07 to 8.84 & 0.037 \\
\hline SAPS II, per point & 1.00 & 0.99 to 1.01 & 0.493 & & & \\
\hline \multicolumn{7}{|l|}{ Reason of mechanical ventilation } \\
\hline Neurological disease & 1 (reference) & & & 1 (reference) & & \\
\hline Chronic pulmonary disease & 0.94 & 0.31 to 2.85 & 0.916 & 0.82 & 0.22 to 3.07 & 0.773 \\
\hline Acute respiratory failure without a priori risk for ARDS* & 1.53 & 0.87 to 2.70 & 0.136 & 1.10 & 0.60 to 1.99 & 0.752 \\
\hline Trauma & 2.30 & 1.17 to 4.53 & 0.021 & 1.37 & 0.69 to 2.68 & 0.263 \\
\hline Sepsis & 2.59 & 1.16 to 5.80 & 0.016 & 1.85 & 0.81 to 4.22 & 0.144 \\
\hline Pneumonia & 3.32 & 1.72 to 6.40 & $<0.001$ & 2.15 & 1.00 to 4.65 & 0.050 \\
\hline Aspiration & 4.98 & 2.22 to 11.20 & $<0.001$ & 3.48 & 1.32 to 9.17 & 0.012 \\
\hline Ventilator associated pneumonia & 1.91 & 0.92 to 3.99 & 0.083 & 1.13 & 0.49 to 2.62 & 0.765 \\
\hline \multicolumn{7}{|l|}{ Sepsis over the course of mechanical ventilation } \\
\hline No & 1 (reference) & & & 1 (reference) & & \\
\hline Pulmonary & 2.58 & 1.37 to 4.84 & 0.003 & 1.83 & 0.88 to 3.80 & 0.105 \\
\hline Extrapulmonary & 2.94 & 1.49 to 5.78 & 0.002 & 2.71 & 1.37 to 5.38 & 0.004 \\
\hline Shock over the course of mechanical ventilation & 3.28 & 2.26 to 4.76 & $<0.001$ & 2.50 & 1.62 to 3.87 & $<0.001$ \\
\hline Tidal volume (ml/kg predicted body weight), per unit & 1.02 & 0.97 to 1.07 & 0.469 & & & \\
\hline PEEP, per cmH2O & 1.31 & 1.22 to 1.39 & $<0.001$ & 1.04 & 1.01 to 1.07 & 0.006 \\
\hline
\end{tabular}

*This variable includes: Postoperative acute respiratory failure, congestive heart failure, cardiac arrest.

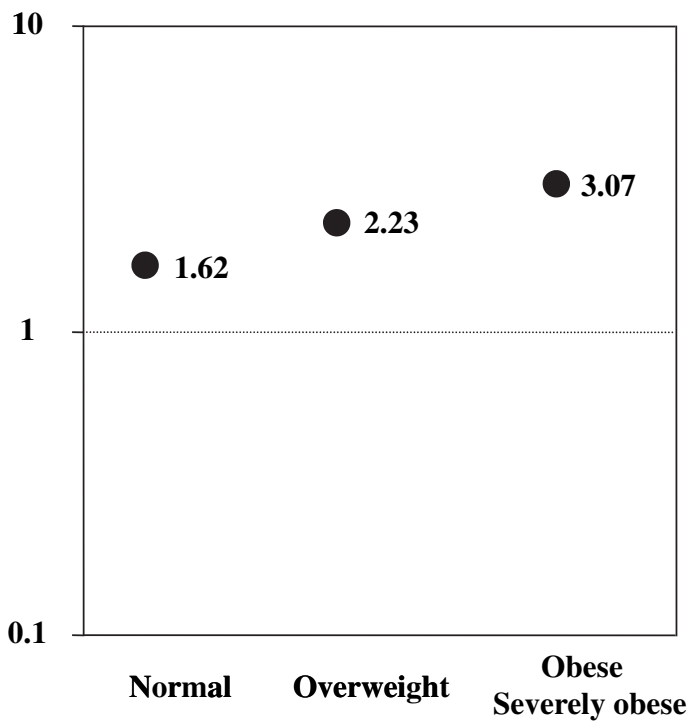

Figure 1 Adjusted OR for the development of acute respiratory distress syndrome. The reference group is patients in the underweight category. OR for acute respiratory distress syndrome was adjusted by age, SAPS II, sex, reason to start mechanical ventilation, body mass index, risk factors for acute respiratory distress syndrome developed over the course of mechanical ventilation (sepsis, shock, and ventilator associated pneumonia), tidal volume and positive end-expiratory pressure. critically ill patients ${ }^{4}$; obese patients were more likely to develop acute respiratory distress syndrome and acute renal failure; and body mass index was not associated with mortality nor a longer stay in the intensive care unit.

Our study is a prospective report that evaluates the impact of body mass index on clinical outcomes in a large cohort of patients receiving mechanical ventilation. Obesity and mechanical ventilation could interact through a number of mechanisms. Obese patients have reduced respiratory system compliance $^{11}$ leading to high airway pressures and they can frequently receive tidal volumes that can be excessive when judged according to predicted body weight by height (a better approximation of lung size). Obese patients are prone to atelectasias, aspiration and pneumonia that may increase the duration of mechanical ventilation. Despite these handicaps, we did not find differences in the duration of mechanical ventilation nor in the time devoted to weaning from mechanical ventilation in obese patients.

In published studies, there are discrepancies on the influence of obesity on mortality. These discrepancies may be due to differences in the population included and in the definitions of obesity. Focusing on the studies including only mechanically ventilated patients, ${ }^{6-9} 12$ only one study ${ }^{6}$ reported a higher mortality in obese patients. But, in this study, it is remarkable that the reference mortality in non-obese patients is relative low $(17 \%)$, for a population who received mechanical ventilation longer than $48 \mathrm{~h}$. In our cohort, the mortality of non-obese patients ventilated for more than $48 \mathrm{~h}$ was $32 \%$. In one of the 
Table 5 Comparison of outcomes in each body mass index groups

\begin{tabular}{|c|c|c|c|c|c|c|}
\hline & $\begin{array}{l}\text { Underweight } \\
\left(\mathrm{BMI}<18.5 \mathrm{~kg} / \mathrm{m}^{2}\right)\end{array}$ & $\begin{array}{l}\text { Normal } \\
\left.\text { (BMI } 18.5-24.9 \mathrm{~kg} / \mathrm{m}^{2}\right)\end{array}$ & $\begin{array}{l}\text { Overweight } \\
\left.(B M I) 25-29.9 \mathrm{~kg} / \mathrm{m}^{2}\right)\end{array}$ & $\begin{array}{l}\text { Obese } \\
(B M I) 30-39.9 \text { kg/m²) }\end{array}$ & $\begin{array}{l}\text { Severely obese } \\
\left(B M I>40 \mathrm{~kg} / \mathrm{m}^{2}\right)\end{array}$ & p-Value \\
\hline $\mathrm{N}(\%(95 \% \mathrm{CI}))$ & $184(3.7 \%(3.2$ to 4.3$))$ & $1995(40.1 \%$ (38.8 to 41.5$))$ & $1781(35.8 \%$ (34.5 to 37.2$))$ & $792(15.9 \% ;(14.9$ to 16.9$))$ & $216(4.3 \% ;(3.8$ to 4.9$))$ & \\
\hline $\begin{array}{l}\text { Days of mechanical } \\
\text { ventilation, median (IQR) }\end{array}$ & $4(2,8)$ & $4(2,8)$ & $4(2,8)$ & $4(2,8)$ & $4(2,8)$ & 0.159 \\
\hline $\begin{array}{l}\text { Days of weaning, } \\
\text { median (IOR) }\end{array}$ & $1(1,3)$ & $1(1,2)$ & $1(1,2)$ & $1(1,2)$ & $2(1,3)$ & 0.292 \\
\hline $\begin{array}{l}\text { Length of stay in the } \\
\text { intensive care unit, } \\
\text { median (IOR) }\end{array}$ & $8(4,16)$ & $8(4,15)$ & $8(4,14)$ & $8(5,15)$ & $8(5,15)$ & 0.369 \\
\hline $\begin{array}{l}\text { Mortality in the intensive } \\
\text { care unit, N }(\%(95 \% \mathrm{CI}))\end{array}$ & $60(32.6 \%(25.9$ to 35.9$))$ & $630(31.6 \%(29.5$ to 33.7$))$ & $558(31.3 \%(29.2$ to 33.5$))$ & $227(28.6 \%(25.5$ to 31.9$))$ & $58(26.8 \%(21.1$ to 33.3$))$ & 0.360 \\
\hline $\begin{array}{l}\text { Length of stay in the } \\
\text { Hospital, median (IQR) }\end{array}$ & $18(10,36)$ & $17(9,31)$ & $17(9,31)$ & $17(10,31)$ & $17(9,28)$ & 0.619 \\
\hline $\begin{array}{l}\text { Mortality in the Hospital, } \\
\mathrm{N}(\%(95 \% \mathrm{Cl}))\end{array}$ & $71(38.6 \%(31.5$ to 46.0$))$ & $708(35.5 \%(33.4$ to 37.6$))$ & $655(36.8 \%$ (34.5 to 39.1$))$ & $263(33.2 \%(29.9$ to 36.6$))$ & $63(29.2 \%(23.2$ to 35.7$))$ & 0.141 \\
\hline
\end{tabular}

studies by $\mathrm{O}^{\prime}$ Brien et $a l^{8}$ investigators found that body mass index was associated with risk-adjusted hospital mortality among mechanically ventilated adults with acute lung injury. Lower body mass index was associated with higher odds of death, whereas overweight and obese were associated with lower odds. We found a similar trend although we did not find statistically significant differences between categories of body mass index.
How to set ventilator parameters such as tidal volume and PEEP in obese patients is not clearly defined. The impact of body weight on lung mechanics has important implications in the selection of ventilator parameters. Prior reports have shown that obese patients with ARDS were ventilated using significantly higher tidal volumes than those with a normal body mass index. In our study, tidal volumes in obese patients were low $(5-6 \mathrm{ml} /$ $\mathrm{kg}$ ) based on actual body weight, but high $(10-11 \mathrm{ml} / \mathrm{kg})$ based

Table 6 Univariable and multivariable analysis, by generalised estimating equation models, for mortality in the intensive care unit

\begin{tabular}{|c|c|c|c|c|c|c|}
\hline & Univariable & & & Multivariable & & \\
\hline & $\mathbf{O R}$ & $95 \% \mathrm{Cl}$ & $\mathrm{p}$-Value & $\mathbf{O R}$ & $95 \% \mathrm{Cl}$ & p-Value \\
\hline Age, per year & 1.017 & 1.013 to 1.020 & $<0.001$ & 1.011 & 1.006 to 1.015 & $<0.001$ \\
\hline \multicolumn{7}{|l|}{ Gender } \\
\hline Male & 1 (reference) & & & & & \\
\hline Female & 0.96 & 0.85 to 1.08 & 0.514 & & & \\
\hline Underweight & 1 (reference) & & & & & \\
\hline Normal & 0.91 & 0.67 to 1.25 & 0.573 & & & \\
\hline Overweight & 0.89 & 0.65 to 1.23 & 0.506 & & & \\
\hline Obese & 0.87 & 0.62 to 1.22 & 0.422 & & & \\
\hline Severely obese & 0.80 & 0.53 to 1.22 & 0.302 & & & \\
\hline Simplified acute physiology score, per point & 1.040 & 1.036 to 1.044 & $<0.001$ & 1.032 & 1.037 to 1.036 & $<0.001$ \\
\hline \multicolumn{7}{|l|}{ Reason of mechanical ventilation } \\
\hline Neuromuscular disease & 0.95 & 0.47 to 1.91 & 0.887 & & & \\
\hline Trauma & 1.00 & 0.70 to 1.43 & 0.965 & & & \\
\hline Chronic obstructive pulmonary disease & 1.29 & 0.92 to 1.82 & 0.132 & & & \\
\hline Congestive heart failure & 1.89 & 1.39 to 2.58 & $<0.001$ & 1.59 & 1.15 to 2.20 & 0.004 \\
\hline Other acute respiratory failure & 2.03 & 1.55 to 2.66 & $<0.001$ & 1.78 & 1.35 to 2.35 & $<0.001$ \\
\hline Coma & 2.27 & 1.82 to 2.83 & $<0.001$ & 2.04 & 1.62 to 2.57 & $<0.001$ \\
\hline Aspiration & 2.68 & 1.82 to 3.92 & $<0.001$ & 2.03 & 1.36 to 3.03 & $<0.001$ \\
\hline Community pneumonia & 2.81 & 2.14 to 3.69 & $<0.001$ & 2.34 & 1.76 to 3.12 & $<0.001$ \\
\hline $\begin{array}{l}\text { Chronic pulmonary disease non-chronic obstructive pulmonary } \\
\text { disease }\end{array}$ & 3.33 & 2.10 to 5.30 & $<0.001$ & 4.53 & 2.75 to 7.46 & $<0.001$ \\
\hline Hospital pneumonia & 3.52 & 2.45 to 5.06 & $<0.001$ & 2.93 & 2.01 to 4.28 & $<0.001$ \\
\hline Cardiac arrest & 4.43 & 3.26 to 6.02 & $<0.001$ & 2.64 & 1.92 to 3.64 & $<0.001$ \\
\hline
\end{tabular}




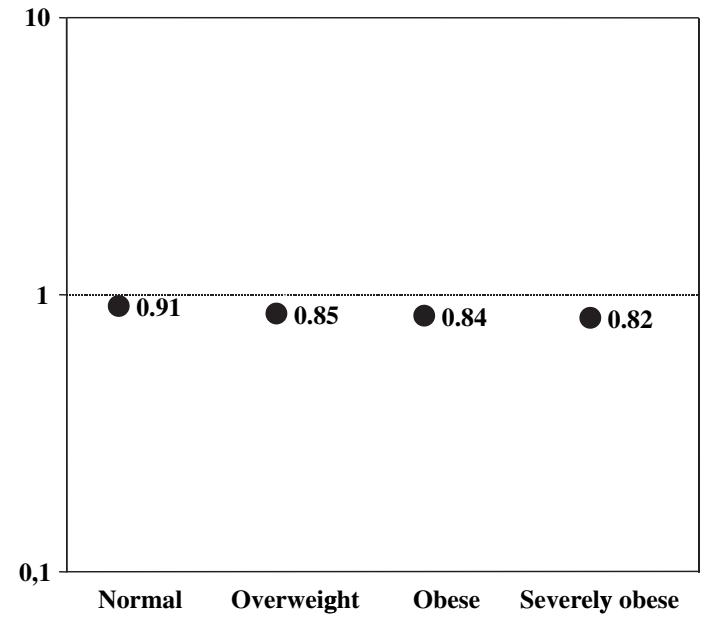

Figure 2 Adjusted OR for mortality in the intensive care unit. The reference group is patients in the underweight category. OR for mortality was adjusted by age, sex, SAPS II, body mass index category, type of ventilation (invasive ventilation vs. failed non-invasive ventilation vs. successful non-invasive ventilation), and reason for initiating mechanical ventilation.

on predicted body weight, along with higher levels of PEEP. These data suggest that clinicians overestimated lung size for obese patients and chose tidal volumes on the basis of actual body weight rather than predicted body weight. Observational studies indicate an association between high tidal volumes in patients mechanically ventilated due to an extra-pulmonary condition and at an increased risk to develop acute lung injury. ${ }^{13}$ That is, using high tidal volumes could place obese and severely obese patients at risk for ventilator-associated lung injury. Our analysis, however, along with results reported by Gong et a $1^{14}$ show that obesity, independent of tidal volume or airway pressures, is related with the development of acute respiratory distress syndrome. It is possible that obesity may play a significant role in the pathogenesis of pulmonary diseases through mechanisms that may involve pro-inflammatory mediators produced in the adipose tissue that contribute to a state of systemic inflammation. ${ }^{15}$ Alternatively, the increase in ARDS among obese patients may be artifactual with obese patients being more likely to have opacities seen on chest radiograph because of increased tissue mass and more likely to have hypoxaemia because of other reasons such as atelectasis. However, the fact that ARDS at baseline was seen less commonly in obese patients points away from this supposition.

Several authors have reported a higher incidence of organ dysfunctions in obese patients. ${ }^{16-18}$ Our study also showed the presence of organ dysfunctions, but like in other studies this was not associated with higher mortality. Slynkova et al, ${ }^{19}$ in an analysis of 15408 participants in the Atherosclerosis Risk in Communities Study, found that obesity by itself was not a significant predictor of either acute organ failure or death. However, the presence of diabetes mellitus, which is related to obesity, was a strong predictor of both acute organ failure and death after acute organ failure. Recently, similar to our results, a large meta-analysis evaluated the effect of obesity on intensive care morbidity and mortality. These investigators reported that obese patients, despite having increased morbidity, have no change in mortality. ${ }^{3}$ A possible explanation for the 'paradox' of how a condition that is associated with multiple chronic morbidities could be protective in the face of critical illness is the possibility that the large mass of adipose tissue serves as an adipokine factory, producing a predominance of anti-inflammatory cytokines, such as interleukin-10 and leptin. The elevation of leptin in septic patients has been associated with survival in some studies. ${ }^{3} 20$

There are several limitations to our study. The distribution of obesity may vary across study centres and countries. It is possible that our study did not fully evaluate the population at risk. Obese and severely obese patients may have chosen not to receive mechanical ventilatory support and or clinicians may have avoided these methods of support based on patients' weight. Thus, selection biases may have influenced the decision to ventilate a patient in the first place. Once patients were admitted to the study intensive care unit, we believe that these issues did not play a role because we enrolled sequential patients that required invasive or non-invasive mechanical ventilation during a 1-month period. There are other factors that may influence patient's weight, such as fluid balance, that are not taken into consideration. In others to avoid this problem we used the weight obtained at intensive care unit admission for this analysis.

In conclusion, a significant number of patients that received mechanical ventilation in our cohort had increased body weight, and $20 \%$ of patients were obese or severely obese. Obese patients were ventilated with high tidal volumes based on predicted body weight. These patients were more likely to have significant complications during the course of ventilatory support including acute respiratory distress syndrome and acute renal failure, but there were no associations with increased duration of mechanical ventilation, length of stay or mortality. Due to an increasing incidence of increased body weight in the general population, it is likely that more overweight patients will require mechanical ventilation in the future. Our data show that obesity is not a factor that adversely affects patient outcomes in the ICU, if anything it may be protective.

Acknowledgements Authors acknowledgement to Javier Zamora from Departamento de Bioestadística of Hospital Ramón y Cajal (Madrid, Spain) the statistical support.

Funding Other Funders: CIBER Enfermedades Respiratorias, Instituto Carlos III, Madrid, Spain.

Competing interests None.

Ethics approval This study was conducted with the approval of the study protocol was approved by local Institutional Review Boards of all the participating centers with a waiver for consent.

Provenance and peer review Not commissioned; externally peer reviewed.

\section{REFERENCES}

1. National Task Force on the prevention and treatment of obesity. Overweight, obesity and health risk. Arch Intern Med 2000;160:898-904.

2. Flegal KM, Carroll MD, Ogden CL, et al. Prevalence and trends in obesity among US adults, 1999-2008. JAMA 2010;303:235-41.

3. Akinnusi M, Pineda L, El Solh A. Effect of obesity on intensive care morbidity and mortality: a metaanalysis. Crit Care Med 2008;36:151-8.

4. Oliveros H, Villamor E. Obesity and mortality in critically ill adults: a systematic review and meta-analysis. Obesity 2008;16:515-21.

5. Hogue CW, Stearns JDS, Colantuoni E, et al. The impact of obesity on outcomes after critical illness: a meta-analysis. Intensive Care Med 2009;35:1152-70.

6. Bercault N, Boulain T, Kuteifan K, et al. Obesity-related excess mortality rate in an adult intensive care unit: a risk-adjusted matched cohort study. Crit Care Med 2004;32:998-1003

7. Frat JP, Gissot V, Ragot $\mathrm{S}$, et al. Impact of obesity in mechanically ventilated patients: a prospective study. Intensive Care Med 2008;34:1991-8.

8. O'Brien JM, Welsh $\mathrm{CH}$, Fish $\mathrm{RH}$, et al. Excess body weight is not independently associated with outcome in mechanically ventilated patients with acute lung injury. Ann Intern Med 2004;140:338-45.

9. Morris AE, Stapleton RD, Rubenfeld GD, et al. The association between body mass index and clinical outcomes in acute lung injury. Chest 2007;131:342-8.

10. Esteban A, Ferguson ND, Meade MO, et al. Evolution of mechanical ventilation in response to clinical research. Am J Respir Crit Care Med 2008;177:170-7. 
11. Salome CM, King GG, Berend N. Physiology of obesity and effects on lung function. $J$ Appl Physiol 2010;108:206-11.

12. Yaegashi M, Jean R, Zuriqat $\mathbf{M}$, et al. Outcome of morbid obesity in the intensive care unit. J Intensive Care Med 2005:20:147-54.

13. Gajic 0, Frutos-Vivar F, Esteban A, et al. Ventilator settings as a risk factor for acute respiratory distress syndrome in mechanical ventilated patients. Intensive Care Med 2005;31:922-6.

14. Gong MN, Bajwa EK, Thompson BT, et al. Body mass index is associated with the development of acute respiratory distress syndrome. Thorax 2010;65:44-50.

15. Mancuso P. Obesity and lung inflammation. J Appl Physiol 2010;108:722-8.
16. Neville A, Brown C, Weng J, et al. Obesity is an independent risk factor of mortality in severely injured blunt trauma patients. Arch Surg 2004;139:983-7.

17. Brown C, Neville A, Rhee P, et al. The impact of obesity on the outcomes of 1,153 critically injured blunt trauma patients. J Trauma 2005:59:1048-51.

18. Ciesla D, Moore E, Johnson J, et al. Obesity increases risk for organ failure after severe trauma. J Am Coll Surg 2006;203:539-45.

19. Slynkova K, Mannino DM, Martin GS, et al. The role of body mass index and diabetes in the development of acute organ failure and subsequent mortality in an observational cohort. Crit Care 2006;10:R137.

20. Andrews WR. Obesity and intensive care unit survival: pass the potatoes? Crit Care Med 2008;36:369-70.

\section{Lung alert}

\section{Vitamin B deficiency may increase risk of lung cancer}

It has been hypothesised that deficiencies in B vitamin levels may influence gene expression by means of aberrant methylation patterns as vitamin B is essential for DNA synthesis and methylation. This study investigated the role of B vitamins (B2, B6, B9, B12) and methionine status on the development of lung cancer. It was conducted over 8 years and included participants from the EPIC (European Prospective Investigation into Cancer and Nutrition) cohort.

899 cases were suitable for serum analysis. Using sex, smoking and age-specific incidence rates, cumulative risks of lung cancer were greatest for current smokers followed by former smokers and never smokers. After adjusting for matching variables and cotinine (a marker of smoking), a substantially lower risk of lung cancer was seen for increasing levels of B6 and methionine. The study also revealed a high deficiency in nutrient levels of B vitamins in many western populations. Smokers were found to consume fewer fruits and vegetables (B vitamins source). Smoking intensity was inversely associated with folate, B12 and B6 levels. Serum levels of B vitamins and metabolites were ascertained to be partially determined by diet and clearly affected by vitamin supplements so low vitamin levels were found to be modifiable.

This study suggests that smoking and dietary intake can have an impact on lung cancer development. Although previous studies of vitamin B supplementation in other cancers have not been shown to be of benefit, this is clearly an interesting area for further development.

- Johansson M, Relton C, Magne Ueland P. Serum B vitamin levels and risk of lung cancer. JAMA 2010;303:2377-85.

\section{Omar Hashmi}

RMO, HDU, Karachi, Pakistan

Correspondence to Dr Omar Hashmi, RMO, HDU, 46-D Block 4 Federal B Area, Karachi 78400, Pakistan; drowh@live.com

Published Online First 29 September 2010

Thorax 2011;66:73. doi:10.1136/thx.2010.150235 